\title{
LITERACY AND DEAF EDUCATION
}

\section{LETRAMENTO E EDUCAÇÃO DE SURDOS}

\author{
Aryane S. Nogueira \\ Universidade Estadual de Campinas, Campinas, São Paulo, Brasil
}

\begin{abstract}
This paper addresses literacy from the perspective of deaf education studies ${ }^{1}$, analyzing how this concept has reframed understandings about educational practices for deaf students, more specifically, the teaching of reading and writing in Portuguese. Based on three publications, two in the early 2000 s related to scientific events in the field and a more recent one from 2018, we intend to show that a dialog was initially constructed between the concept of literacy as social practice and the sociolinguistic concept of bilingualism, which has been re-appropriated as a bilingual education project for the deaf. During this process, specific language practices have been established that have direct implications on how classroom literacy for deaf students has been seen until the present time.
\end{abstract}

Keywords: Literacies; Language Education; Deaf Education; Minorities

Resumo: Neste artigo tematizamos o conceito de letramento a partir da sua retomada nos estudos sobre educação de surdos ${ }^{1}$. Analisamos e argumentamos como esse conceito foi alçado para ressignificar o entendimento das práticas escolares desenvolvidas com alunos surdos, mais especificamente, o ensino da leitura e da escrita em português, num conjunto de textos pertencentes a três publicações - duas do início dos anos 2000, relacionadas a eventos científicos relevantes na área, e outra mais recente, do ano de 2018. Conforme pretendemos mostrar, esses trabalhos constroem, inicialmente, uma interlocução entre o conceito de letramento como prática social e o conceito sociolinguístico de bilinguismo (re)apropriado ao projeto de educação bilíngue para surdos. Nesse processo, instauram-se práticas de língua(gem) específicas a esse contexto, com repercussões diretas no modo como o letramento em sala de aula com alunos surdos vem sendo pensado até os dias de hoje.

Palavras-Chave: Letramentos; Educação Linguística; Educação de Surdos; Minorias

\footnotetext{
1 This discussion began in Nogueira (2015) and has had a direct relationship with the development of the FAPESP research project "Semiotic Repertory and Education of the Deaf: Multilingualism and Multimodality in the Context of Sign Language" (n.2017/20256-0), as well as a current postdoctoral research project entitled "Interfaces entre o português e os repertórios sociossemióticos de aprendizes surdos" (Interfaces between Portuguese and socio-semiotic repertories of deaf learners).
} 


\section{INTRODUCTION}

In the mid-1990s and early 2000s, a new vision of literacy studies emerged in Brazil that contrasted with earlier research, since to understand the way literacies practices functions in both society and the classroom, research focused on linguistic and cognitive issues alone no longer seemed sufficient, given that it obfuscates more complex understandings of literacies as cultural phenomena (SIGNORINI, 2004). Pioneering studies by Heath (1983) and Street (1984), which adopted the sociocultural perspective that literacy is a contextual and culturally situated social practice, were taken up by Brazilian researchers such as Kleiman (1995), Rojo (1998), Signorini (2001) and Terzi (2001), resulting in a movement to understand literacy as a social practice that enabled the resignification of: (a) the relationship between oral and written language, (b) concepts of writing and text in literacy practices and (c) concepts of literacy and teaching practices of writing at schools.

We perceive two opposing ways of understanding the concept of literacy when it is being translated into language education actions. An autonomous view of literacy (e.g., STREET, 1984) that confuses the teaching-learning of reading and writing with the process of alphabetizing itself. In this view, writing is understood as a transcription of orality to be learned in a linear and cumulative process, with students initially developing cognitive and linguistic skills, first as letters, followed by syllables, words and phrases until they reach the domain of texts, when they are then able to read and write (BARTON, 1994). Thus, in developing coding and decoding skills, students come into contact with texts, which are primarily written and are understood as communicative units whose meanings, both stable and finished, are waiting to be understood by the students (CASSANY, 2010, 2016 ${ }^{2}$ ).

On the other hand, an ideological and sociocultural perspective of literacy considers that it is embedded in broader social practices in which reading and writing are integral including different types of texts in various modalities - and that different socioculturally situated values and functions are attributed to the varied practices established by different social groups (STREET, 2003; SIGNORINI, 2004). Thus, texts, in a broader sense, are social and political artifacts, whose meanings are situated. When this movement is translated into language education, the teaching-learning of reading and writing is understood as a process of participation in (BLOOME; RYU, 2017, p. 287) and appropriation of practices, i.e. reading and writing are ways of acting in the world, doing things, taking roles, building identities, and exercising power (CASSANY, 2010; 2016).

In Brazil, the beginning of the dialogue between literacy studies and deaf education can be traced to the initial conception of literacy as a social practice, as a means of redefining the concepts of literacy and the teaching of writing in schools. This resulted, as we intend to show, in problematization of language education practices in deaf education studies in an attempt to implement a bilingual education project that recognizes the linguistic difference of deaf students. This article will reflect on this dialogue and trace some of its developments, namely: the construction of the concept of literacy in the field of deaf education, the reverberations this has had on language education and classroom literacy practices until the present day.

Our reflections are based on a brief historical survey that reveals characteristics of the point when the transformative movement in deaf education and the development of the concept of literacy in research aligned, and on the processes of developing the concept of literacy in deaf education research through an analysis of three publications in the area. The first, entitled Letramento e Minorias (Literacy and Minorities), was published in 2002 and is a

\footnotetext{
${ }^{2}$ Notes from a lecture by Prof. Daniel Cassany (Universitat Pompeu Fabra - Barcelona) at Escola de Altos Estudos (School of High Studies) at the Universidade Estadual de Campinas (UNICAMP - IEL) in 2016.
} 
result of an eponymous scientific event, the First Literacy and Minorities Forum, held in March of that year at the Universidade Metodista de Piracicaba, in the state of São Paulo.

The following March, the Second Literacy and Minorities Forum was held at the Rotary Foundation of São Paulo, organized jointly by three educational institutions: the Universidade Metodista de Piracicaba, the Division of Education and Rehabilitation of Communication Disorders of the Pontifícia Universidade Católica de São Paulo and the São Paulo Rotary Foundation's Special School for Deaf Children. This event resulted in a book entitled Leitura e Escrita: no Contexto da Diversidade (Reading and Writing: in the Context of Diversity) (2004), which is analyzed herein, together with the previously mentioned publication, as milestones that, due to the way they approach the concept of literacy in deaf education, represent a theoretical vanguard (LODI, 2012, p. 10) approach in deaf education studies.

As explained by the organizers of Letramento e Minorias (2002), the event's idealization and achievement, especially the initial Forum, was motivated by discussion at the sixth Congresso Latinoamericano de Educación Bilingüe y Bicultural para Sordos (Latin American Congress of Bilingual and Bicultural Education for the Deaf), which was held in Santiago, Chile, in July 2001 and whose theme was reading and writing education for deaf children and young people with a bilingual and bicultural approach ${ }^{3}$. This indicates attention was being paid to cultural and linguistic aspects (mainly bilingual) of language education practices for the deaf.

The third publication, entitled Letramento na diversidade: surdos aprendendo a ler/escrever (Literacy in Diversity: deaf people learning to read/write) (2018), we observe the nature of studies on deaf literacy nearly twenty years after the initial publications.

\section{LITERACY AND THE BILINGUAL MINORITY CONTEXT OF DEAFNESS: CROSSING PATHS}

[...] the other is an Other and literacy is a literacy of otherness [...] (SKLIAR, 2002, p.11, my translation $)^{4}$.

Skliar's epigraph (2002), taken from the preface of Letramento e Minorias (2002), alludes, quite well, to the moment when the paths of literacy studies and deaf education crossed. As indicated above, the concept of literacy indicates a literacy of otherness, since it no longer functions as a direct translation of a single literacy practice, being distanced from a graphocentric lens and encompassing, in the various possibilities of writing practices, the agency of different social groups, which mirror their linguistic, cultural and identity differences.

The concept of literacy was changing, and the deaf were also no longer the same, according to Skliar (2002). Since the late 1980s and early 1990s, discussion about bilingual education for the deaf has been ongoing in Brazil due to: (1) certain theorists' interest in the description of Sign language (LODI, 2012) and (2) deaf social movements that began to press for recognition of their language and changes in education (MONTEIRO, 2006).

At the end of the 1990s, the concept of bilingualism became part of educational policies for the deaf that reflected: the political struggle of the deaf and some hearing people to expose problems in deaf education; the contribution of research in linguistics, applied linguistics and education that pointed out the need for Sign language to be used as a means of

\footnotetext{
${ }^{3}$ Information about this congress was retrieved from: http://sid.usal.es/cursos-y-congresos/discapacidad/339/13/vi-congreso-latinoamericano-de-educacion-bilingue-bicultural-para-sordos.aspx Acess: 04 April. 2019.

${ }^{4}$ Original quote: "[...] o outro é Outro e o letramento é um letramento outro [...]."
} 
communication and instruction, as well as the incorporation of this new knowledge in government agendas, which culminated in formalizing Brazilian Sign Language (Libras) with Federal Law 10.436 in 2002, including implementation of Libras in schools through decree 5.626 in 2005.

It should be clarified that the term bilingualism, in sociolinguistic literature, originally refers to the use of more than one language, not necessarily in education and, in its early days, did not encompass deaf individuals, who appropriated the term. What is called bilingualism with regard to the deaf refers to a bilingual education project that defends the deaf child's exposure to Sign language from a very early age, which is considered their most naturally acquirable language, and then later to a second language, which in Brazil would be written Portuguese and, when possible/desirable, oral Portuguese.

The bilingual movement in deaf education has been based on recognizing deafness as a difference (SKLIAR, 1997; 1998) rather than as a medical-pathological condition, which has repercussions mainly, but not only, on language education. This new view of deafness arose through recognition of the impact caused by the discourse of disability and led to a search for other representations of deafness, i.e., as a minority and as difference.

The purpose of describing the deaf as a minority (SKLIAR, 2002) or as a minority linguistic group (CAVALCANTI, 1999; 2011) is not to demarcate a group that is numerically smaller, but one that is deprived of recognition and value in their difference, especially regarding culture and language. In a process of alterization, as explained by Skliar (2002, p. 11 ), the concept of the deaf as a minority is understood in the sense of a "[...] group that moves away of its own volition, that is neither underestimated nor reveals itself, but simply moves away. That wants to get away" (my translation) ${ }^{5}$ and, we add, moves away in order to establish its difference. This process directly presupposes recognition of deaf visual experience, which encompasses visual-gestural language as a form of communication, as well as the development of primarily visual structures, forms and cognitive functions (SKLIAR, 1997).

A mobilization emerged in this paradigm shift whose purpose was to reorganize the presuppositions that govern deaf education, i.e., to recognize deafness as a difference characterized by diverse visual and linguistic experience, rather than the educational methodology, followed particularly in schools for the deaf, of teaching from a rehabilitative oralist $^{6}$ logic (SKLIAR, 1998). It was incompatible to conceive of deaf education in terms of methods for developing speech in order to overcome a linguistic incapacity and as a prerequisite for the acquisition of writing. Moreover, it was incompatible with the way in which deaf education had been organized since the 1990s, when a national policy of inclusion began to gain momentum.

As has been pointed out by a number of authors (see LACERDA, 2006), in regular schools, deaf students were immersed in education practice that did not consider their difference, having been developed and organized in Portuguese for the hearing majority, with no curricular adaptations. Fernandes $(2008$, p. 9) explains that although deaf students did not need to undergo speech rehabilitation training in regular schools, the then current teaching methodology for reading and writing, which was organized "from the part to the whole," made little sense to them, since despite increased focus on reading and writing from texts, sentences, or words, these continued to function as a systematization of syllables, letters, and phonemes, i.e., to establish a letter-sound relationship.

\footnotetext{
${ }^{5}$ Original quote: "[...] grupo que se afasta pela própria vontade, que não se subestima nem se revela, simplesmente se afasta. Que deseja se afastar."

${ }^{6}$ Belief in such methods was based on the idea that the development of speech by the deaf, i.e., the acquisition of knowledge about the phonological aspects of the language, culminated, naturally and directly, in the learning of writing - as they believed happened with hearing students.
} 
For literacy scholars, who, it should be emphasized, do not address the subject of deafness in their work, examining the teaching of writing through the ideological lens of the concept of literacy corroborates the difference between typical school literacy practice, i.e., familiarizing students with the alphabet and the mechanics of reading and writing, and other literacy practices in the larger society (STREET, 2017; BLOOME; RYU, 2009; ROJO 2009). Consequently, if the domain of coding and decoding skills no longer serves the purposes of language education, i.e. preparing hearing students for meaningful development by using reading and writing for real and effective social participation, how much less relevant would it be for newly integrated deaf students? This paradigm affected their participation in three ways: first, because the teaching of reading and writing continued to be based on the domain of orality; second, the mediation of the teaching-learning process itself took place through the teacher's orality, whose instruction and teaching strategies were structured through his or her speech (FERNANDES, 2008); and finally, because all academic learning was based on the student's commitment to reading and writing Portuguese, a language difficult for deaf students to acquire because of the way it was taught.

Thus, in the larger movement to rethink education, the paths between a literacy of otherness and another Other intersect. According to Teske (2012, p. 31), the deaf education social movement and the literacy movement are "[...] processes related to the current political system" (my translation) ${ }^{7}$ that both strive after deeper understanding of and broader limits for literacy discourse and practice and, in this process, seek change in the rules, political procedures and forms of participation in political systems (TESKE, 2012, p. 31).

\section{ASPECTS OF LITERACY IN BRAZILIAN DEAF EDUCATION}

\section{Initial contributions}

Letramento e Minorias (2002) and Leitura e escrita: no contexto da diversidade (2004) include texts written by researchers principally affiliated with four fields of study: education, applied linguistics, linguistics and psychology (the latter being less expressive). Letramento e Minorias (2002) contains a total of seventeen chapters, of which nine (in addition to the preface) specifically address issues related to deaf education. Leitura e escrita: no contexto da diversidade (2004), on the other hand, contains twelve chapters, of which seven focus on deaf education.

Based on an analysis of these chapters written in the early 2000 s, we observed that discussion of deaf education involved, first of all, acquiring knowledge about literacy as a social practice (see definition in STREET, 2017). With such a foundation, a bilingual project was constructed that conceptualized deafness as a difference and the deaf as a minority, presupposing that education practices do not work without considering cultural and linguistic issues.

Recognizing the deaf as a minority who wish to make a difference in various social spaces, these studies discussed the need for literacy in deaf education, which is understood as a literacy of otherness unique to the deaf (SKLIAR, 2002, p.10). These studies recognize in the deaf difference, particularly the linguistic difference, a basis for developing new practices in schools, so that those who self-identify as deaf can be educated (SOUZA, 2002, p.143). In proposing other classroom practices based on the deaf difference, space is opened for the defense, for example, of a deaf pedagogy (RANGEL; STUMPF, 2004); for practical experience with written Sign language (signwriting) as a way of legitimizing the language and individuality of the deaf in schools (STUMPF, 2002); for analysis of Sign language

\footnotetext{
${ }^{7}$ Original quote: “[...] processos em relação ao sistema político vigente”.
} 
storytelling in order to understand how these practices could help restructure Portuguese language teaching for the deaf (ALVES; KARNOPP, 2002); or even for examination of classroom literacy experiences with deaf students for whom, due to new legislation recognizing their specific situation, professional sign language interpreters have been provided in the classroom, which requires further reconfiguration of the academic environment (HARRISON; NAKASATO, 2004; LACERDA, 2002; SANDER, 2002).

On the other hand, these studies also point to the non-recognition of the deaf linguistic and cultural difference, which is reflected in the invisibility of the deaf linguistic environment, i.e. visuospatial communication that "produces forms of understanding, interpretation and narration of the world based on a visual culture" (GIORDANI, 2004, 78; my translation $)^{8}$. Instead, literacy practices based on the letter-sound relationship are perpetuated, which result, for example, in deaf students' feigned participation in regular schools, i.e., mere repetition of classroom rituals as a way of belonging (GÓES; TARTUCI, 2002, p. 117).

According to Ibrahim (2017), the failure of language education in a majority language is what motivates researchers and educators look to the experience of minority language students in language classrooms in order to improve teaching-learning processes. In this process, the minority language is considered a psychological and social basis for identification and communication within minority groups, a delicate association of psycholinguistic and sociocultural/sociopolitical factors. This association has begun to predominate in language and literacy education research, leading to the understanding that literacy in a minority language is not detrimental to the development of a second language but, on the contrary, benefits when developed alongside second language literacy.

Ibrahim (2017) locates this movement in the late twentieth century in early studies on literacy in more than one language. These studies mainly addressed the development of reading and writing in a second language, usually that of the majority community, finding a strong connection between the concepts of language and identity ${ }^{9}$. We observe this movement, analogously, in initial research on literacy in deaf education.

Lodi et al. (2002, p. 35), for example, based on Kleiman (1995), Rojo (2001) and Signorini (2001), reported that " [...] literacy practices are plural, determined socio-historically and culturally, and understood as a continuum [...] between oral and written practices, thus extrapolating the universe of writing" (my translation) ${ }^{10}$. Thus, the authors established that Sign language, being considered and developed as the first language (L1) of the deaf, should be used when teaching Portuguese as a second language (L2) to benefit deaf students. Since both writing and orality occupy space in literacy practice developed from a social perspective, appropriation of this concept allows Sign language to be considered the "orality" of the deaf (LODI, 2004).

Karnopp and Pereira (2004) appropriated the concept of literacy presented in Soares (1998), Kleiman (1995), Rojo (1998) and Tfouni (2002) to discuss how deaf education processes could be improved. In this discussion they assumed that for deaf individuals, visual language must be considered the L1 (PEREIRA, 2002), making it a prerequisite for acquiring reading and writing skills in Portuguese. They defended the reorganization of language education practice with a new focus on the text as a whole, rather than isolated words: "first

\footnotetext{
${ }^{8}$ Original quote: "produz formas de apreensão, interpretação e narração do mundo a partir de uma cultura visual."

${ }^{9}$ Some of the examples of research cited by this author are: Skutnabb-Kangas and Toukomaa (1976), Cummins (1979), Grosjean (1982) and Fishman (1980).

${ }^{10}$ Original quote: "[...] as práticas de letramento são plurais, determinadas sócio, histórica e culturalmente, e compreendidas a partir de um contínuo [...] entre práticas orais e escritas, extrapolando, assim, o universo da escrita."
} 
the use of the language in different contexts and only then proceed to the teaching of grammar [...]" (KARNOPP; PEREIRA, 2004, p. 36, my translation) ${ }^{11}$. In this process, Sign language has gained a prominent role: (a) in expanding deaf students' knowledge of the world, so that they can recontextualize and give meaning to writing (PEREIRA, 2002, p. 49), and (b) in the strategic use of the students' prior linguistic knowledge, which is employed in reading and the textual analysis and production processes, since they will repeatedly ask themselves: "What is the sign for that word?" (KARNOPP, 2002, p. 59).

Based on Ibrahim (2017, p. 212), we understand that Lodi et al. (2002), Pereira (2002), Karnopp (2002) and Karnopp and Pereira (2004) form, along with previously mentioned studies, a body of publications emphasizing that the failure to educate the deaf has been directly related to the presuppositions that delimit teaching practice, determined through a monolingual and assimilatory lens that negatively impacted the language learning of the deaf. Thus, they proposed the development of both languages, the minority and the majority, with special attention to the minority language in teaching situations as a way of giving voice to minority groups, promoting cultural transmission and strengthening minority identity so that the educational process could be successful. We point out, in particular, that this movement succeeded in revealing that an interface between the linguistic resources of Portuguese and Sign language emerged from these researchers' conception of new literacy teaching practices for deaf students.

Regarding the interface between Portuguese and Sign language, we highlight two studies published in Leitura e escrita: no contexto da diversidade (2004) that, through recognizing and appreciating deaf difference as a visual experience in the educational space, add visual semiotic resources as a third element in the interaction of linguistic resources, establishing a tripartite system of reading and writing education practices for deaf students.

In a study that analyzed written texts by deaf students, Gesueli $(2004$, p. 41$)$ drew attention to the interface of Portuguese with Sign language in the process of deaf literacy education, concluding that language skills intertwine. According to the sample of texts, visual expression was a writing component, and Gesueli $(2004$, p. 47) defended that deaf literacy practices should be: (a) based on a relationship between the signs of Sign language, the written word and images, and that (b) images should be allowed in texts produced by deaf students, since the images found in the sample were not mere illustrations, but produced meaning in association with the written word.

Campos et al. (2004) described the interface between Sign language, Portuguese and visual resources in a study on Portuguese education in a school for the deaf. When reading and translating texts, whether in words alone or accompanied by images, it was observed that both written texts (with or without images) and texts translated into Sign language involved a visual aspect, which evoked awareness of the importance of the text's visuality among teachers. It was concluded that visuality should be explored when teaching Portuguese as a second language to the deaf to optimize student independence and engagement with reading.

In summary, publications from the early 2000s envisioned literacy as a social practice (STREET, 2017), which was then used as a framework for a bilingual deaf education project that was structured, above all, around new classroom practices that are culturally and linguistically responsive (BLOOME; RYU, 2017) to the deaf difference. It should be noted, however, that such a project is based on a very close link between language-culture-identity. Thus, the concept of literacy in deaf education uses this interrelation as a vehicle for minority culture and identity in the classroom, valuing the development of bilingual individuals. In this process, specific language practices have been established for the bilingual literacy of deaf

${ }^{11}$ Original quote: "primeiro o uso da língua em diferentes contextos e só depois procede ao ensino da gramática $[\ldots] "$ 
students in which the interface between Portuguese and Sign language takes at least three forms:

i. $\quad$ Sign language is L1 and Portuguese is L2.

ii. L1 is a condition for L2 teaching and learning.

iii. In the teaching-learning process, there is an interface between L1 and L2 intersected by visual semiotic resources.

Initial research from the 2000s contributed to the concept of deaf bilingual literacy in which importance was given to positively identifying with minority cultures and preserving minority identities, maintaining linguistic and cultural diversity and granting the same status to all languages (IBRAHIM, 2017, p. 213). However, in conceptualizing literacy as an L1/L2 dichotomy, they did not move far from a mono-/bilingual lens and, thus, advanced only timidly toward consideration of non-linguistic communication resources.

\section{Recent contributions}

Although subsequent studies reaffirmed many of the points made in these initial publications from the early 2000s (LODI et al., 2014; LACERDA; LODI, 2014; PEREIRA, 2014; LODI et al., 2012; FERNANDES, 2006; to mention some), culturally and linguistically sensitive bilingual pedagogies have not been implemented in regular schools that admit deaf students. Although Sign language has entered the classroom, definitions of language and monolingual ideologies continue to promote monolingual pedagogies that legitimize "monolingual practices, the idealized native speaker, and the compartmentalization of languages" (IBRAHIM, 2017, p. 219), which did not facilitate the education of deaf students.

Thus, almost twenty years after the initial publications on literacy in deaf education, the topic remains a focus of interest for scholars and researchers. As we observed in the most recent publication, Letramento na diversidade (2018), the concept of literacy continues to serve as a background for research on deaf education, reaffirming the bilingual education project developed in the early 2000s. We also analyze that, in a more or less direct way, the interface of Portuguese with Sign language continues to be the focus of literacy. The difference in current research, however, is in the examination of different aspects of this interface, which result from theoretical alignment with different fields of knowledge.

In a study of the centrality of language in the teaching-learning processes, Silva (2018, p. 42-43) conducted classroom participant observation with deaf students, finding an implicit agreement between the teacher and deaf students that influenced the way students performed reading in typical school literacy practices. The deaf students signed the content of the texts read in Portuguese, visualizing them in different ways to approximate their meaning. According to the author, such literacy practices in written Portuguese were characteristic of the deaf students and indicated that they needed to learn the structure of Portuguese before they could advance in the production of meaning in Portuguese reading activities (p. 69). To frame her reflections, Silva (2018) sought for dialog between the concept of literacy as a social practice within the school context and the linguistic and cognitive issues that arise from linguistic studies on foreign language/second language teaching.

In an ethnographic investigation of schools, Rodrigues (2018, p. 80) analyzed differences in deaf students' participation in classroom literacy practices in both classes of deaf students and classes with deaf students. Relying on contributions from interactional sociolinguistics, the author concluded that "knowledge of the space of these classrooms [classes with and of deaf students] demonstrated that the linguistic question is the central 
aspect of interaction" 12 , and that the use of Sign language was the determining factor for producing teaching-learning opportunities in Portuguese and other disciplines (RODRIGUES, 2018, p. 102).

Based on sociolinguistic and cognitive constructs, Quadros and Sousa (2018, p. 20) analyzed language overlap in bimodal bilingual children and code-switching in young bilingual deaf students learning English as a third language (L3). The authors pointed out that when these processes occur, the speaker is employing the skill of linguistic synthesis, i.e., processing information independently of the linguistic resources that are being deployed. To these authors $(2018$, p. 36), linguistic synthesis in deaf literacy indicates that the different languages contribute to communicative competence through mutual feedback without impeding each other. However, they cautioned, this does not mean that these languages all have the same status in the students' lives. Thus, Quadros and Sousa (2018) explain that they continue assuming that "[...] Libras is the first language of the deaf (the language of comfort, the language in which the curriculum and pedagogy is structured); Portuguese is their second language (especially in the written mode); and a foreign language [...] would be the third language" (QUADROS; SOUSA, 2018, p. 36) ${ }^{13}$.

Using an applied linguistics approach linked to studies about bilingual education in minority contexts, Silva et al. $(2018$, p. 287$)$ raised questions about the lack of complexity in deaf students' language repertoires, specifically the erasure of 'home-made' sign-languages, to discuss deaf students' deficiency in learning scientific concepts in school. The authors concluded that action should be taken to ensure that Sign language is really the language of instruction, so that specific didactic materials and dictionaries could be developed for deaf students, including the use of visual resources as a second language teaching strategy.

In current research, discussion about literacy in deaf education has been framed in a heteroglossic lens, and has examined, for example, the interface between language resources for alternation and overlapping, or even for sociolinguistic complexity in 'home-made' sign languages. Thus, it is not by chance that the interface of linguistic resources has been the focus of literacy research in deaf education, given that the initial studies proposed classroom literacy practices guided by the concept of literacy as social practice, and that they were also aligned with a culturally and linguistically responsive bilingual deaf education project, whose effects on language practices with deaf students have been felt until today. However, for same reason, the concept of literacy in deaf education, although having been researched for almost 20 years and despite its significant contributions to a framework that is more sensitive to the specificities of deaf education, has not been able to distance itself from the dualism (monolingual vs. bilingual, L1 vs. L2) present in research since the early 2000s.

\section{FINAL CONSIDERATIONS AND FUTURE DIRECTIONS}

[...] it is not about being or not being reading and writing, but about 'becoming' reading and writing. Literacy is a process rather than an essence. (SKLIAR, 2002, p. 7 , my translation $)^{14}$

\footnotetext{
12 Original quote: "o conhecimento do espaço dessas salas de aula [turma de surdos e turma com surdos] evidenciou que a questão linguística é o aspecto central da interação."

13 Original quote: "[...] a Libras como primeira língua dos surdos (língua de conforto, língua estruturante do currículo e de toda a pedagogia escolar); o português como segunda língua desses sujeitos (especialmente na modalidade escrita) e a língua estrangeira [...] como terceira língua."

${ }^{14}$ Original quote: "não se trata do ser e não ser da escrita e da leitura e sim do 'estar sendo' da escrita e da leitura. Letramentos é um gerúndio, não é uma essência."
} 
Analysis of these studies on deaf literacy education indicates that the concept of literacy as a social practice has been used as a background in scholarly research (SCHULTZ; HULL, 2017, p. 272) on reading and writing in the classroom, leading to an examination of teaching and its methods in an effort to improve the academic performance of deaf students. Considering the aims and the contexts of these studies, we consider that they also involve discussion about an educational environment that has traditionally disregarded other languages in its space.

These three publications, whose diachrony encompasses almost two decades of studies on deaf literacy education, indicate that although literacy is beginning to involve a heteroglossic approach, this development has been based on a very close link between language-culture-identity and literacy, in which a polarized mono-/bilingual dualism, mainly linguistic-related, has continued to prevail.

However, today's literacy practices have been complicated by new digital technologies that foster communication in a heterogeneous social world that is increasingly globalized and digitized. This change calls for balance to be reestablished between monolingual education practices and the heterogeneity of lived experience, so that classroom activities reflect the multiplicity of communication channels and media, as well as the cultural and language diversity involved in meaning production processes outside the classroom.

Digital interaction and production, for example, require dealing with a creative mix of linguistic and semiotic resources in characteristically translingual, transmodal, and transsemiotic language practices (NOGUEIRA, 2018) that automatically disrupt the cultureidentity-literacy connection (IBRAHIM, 2017, p. 221). If, as Skliar (2002, p. 7) states, literacy is a process ('becoming' reading and writing), we believe that thematic research on literacy in deaf education must dare to look at literacy practices beyond the classroom and rethink education by considering the ways that the deaf 'become' subjects of reading and writing by participating in literacy practices that blur the boundaries between languages, identities and literacies.

\section{Referências}

ALVES, A.C.C.; KARNOPP, L.B. "O surdo como contador de histórias". In: LODI, A.C.B.; HARRISON, K.M.P.; CAMPOS, S.R.L.; TESKE, O. (Orgs.) Letramento e minorias. Porto Alegre: Mediação, 2002, p. 71-75.

BARTON, D. Literacy: an introduction to the ecology of written language. Oxford: Blackwell Publishers, 1994.

BLOOME, D.; RYU, S. "Literacies in the classroom". In: STREET, B.V.; MAY, S. (Eds.) Literacies and Language Education. Springer International Publishing, 2017.

CAMPOS, S.R.L.; KOBER, D.C.; MELENDEZ, A.J. “O recurso midiático como portador de texto no letramento de crianças surdas”. In: LODI, A.C.B.; HARRISON, K.M.P.; CAMPOS, S.R.L. (Orgs.) Leitura e escrita: no contexto da diversidade. Porto Alegre: Mediação, p.50-59, 2004.

CASSANY, D. "Leer y escribir literatura al margen de la ley". In: CILELIJ I Congreso Iberoamericano de Lengua y Literatura Infantil y Juvenil. Actas y Memoria del Congreso. Madrid: Fundación SM/Ministerio de Cultura de España, p. 497-514, 2010. Disponível em: https://www.academia.edu/7130732/Leer_y_escribir_literatura_al_margen_de_la_ley Acess: 10 jan. 2018 
CAVALCANTI, M.C. Estudos sobre a educação bilíngue e escolarização em contextos de minorias linguísticas no Brasil. DELTA, São Paulo. 15 (número especial). p. 385-471, 1999.

CAVALCANTI, M.C. "Multilinguismo, transculturalismo e o (re)conhecimento de contextos minoritários, minoritarizados e invisibilizados: o que isso tem a ver com a formação de professores e com professores em serviço?". In: MAGALHÃES, M.C.C. e FIDALGO, S.S. Questões de método e de linguagem na formação docente. Campinas, SP: Mercado de Letras, 2011.

FERNANDES, S. "Letramento na educação bilíngue para surdos: caminhos para a prática pedagógica". In: FERNANDES, M.C.L; MARÇALO, M.J; MICHELETTI, G. (Orgs.). A língua portuguesa no mundo. São Paulo: FFLCH, 2008. Disponível em: http://www.alex.pro.br/libras3.pdf Acess: 01 mar. 2019

FERNANDES, S. Práticas de letramentos na educação bilingue para surdos. Curitiba: SEED/SUED/DEE, 2006. Disponível em: https://cultura-sorda.org/wpcontent/uploads/2015/03/Fernandes praticas_letramentos-surdos_2006.pdf Acess: 12 April. 2019

GESUELI, Z.M. "A escrita como fenômeno visual nas práticas discursivas de alunos surdos". In: LODI, A.C.B.; HARRISON, K.M.P.; CAMPOS, S.R.L. (Orgs.) Leitura e escrita: no contexto da diversidade. Porto Alegre: Mediação, p. 39-49, 2004.

GIORDANI, L.F. "Encontros e desencontros da língua escrita na educação de surdos". In: LODI, A.C.B.; HARRISON, K.M.P.; CAMPOS, S.R.L. (Orgs.) Leitura e escrita: no contexto da diversidade. Porto Alegre: Mediação, p. 73-85, 2004.

GÓES, M.C.R.; TARTUCI, D. "Alunos surdos na escola regular: as experiências de letramento e os rituais de sala de aula". In: LODI, A.C.B.; HARRISON, K.M.P.; CAMPOS, S.R.L.; TESKE, O. (Orgs.) Letramento e minorias. Porto Alegre: Mediação, p. 110-119, 2002.

HEATH, S.B. Ways with words. Cambridge: Cambridge University Press, 1983.

IBRAHIM, N. "Developing literacy, and identities, in multiple languages". In: STREET, B.V.; MAY, S. (Eds.) Literacies and Language Education. Springer International Publishing, 2017.

KARNOPP, L.B. "Língua de sinais e língua portuguesa: em busca de um diálogo". In: LODI, A.C.B.; HARRISON, K.M.P.; CAMPOS, S.R.L.; TESKE, O. (Orgs.) Letramento e minorias. Porto Alegre: Mediação, p. 56-61,2002.

KARNOPP, L.B.; PEREIRA, M.C.C. "Concepções de leitura e de escrita e educação de surdos”. In: LODI, A.C.B.; HARRISON, K.M.P.; CAMPOS, S.R.L. (Orgs.) Leitura e escrita: no contexto da diversidade. Porto Alegre: Mediação, p.33-38, 2004.

KLEIMAN, A.B. "Modelos de letramento e as práticas de alfabetização na escola". In: KLEIMAN, A.B. (org.) Os significados do letramento: uma nova perspectiva sobre a prática social da escrita. Campinas, SP: Mercado de Letras, 1995. 
LACERDA, C.B.F. A inclusão escolar de alunos surdos: o que dizem alunos, professores e intérpretes sobre esta experiência. Cad. Cedes, Campinas, v.26, n.69, p.163-184, 2006.

LACERDA, C.B.F; LODI, A.C.B. "A inclusão escolar bilíngue de alunos surdos: princípios, breve histórico e perspectivas". In: LODI, A.C.B.; LACERDA, C.B.F. (Orgs.) Uma escola, duas línguas: letramento em língua portuguesa e língua de sinais nas etapas iniciais da escolarização. Porto Alegre: Mediação, 2014.

LACERDA, C.B.F. "O intérprete educacional de língua de sinais no Ensino Fundamental: refletindo sobre limites e possibilidades". In: LODI, A.C.B.; HARRISON, K.M.P.; CAMPOS, S.R.L.; TESKE, O. (Orgs.) Letramento e minorias. Porto Alegre: Mediação, p.120-128,2002.

LODI, A.C.B.; BORTOLOTTI, E.C.; CAVALMORETI, M.J.Z. Literacy of deaf people: language social practices between two languages/cultures. Bakhtiniana, São Paulo, v.9, n.2, p.137-155, 2014.

LODI, A.C.B.; HARRISON, K.M.P.; CAMPOS, S.R.L. (Orgs.) Leitura e escrita: no contexto da diversidade. Porto Alegre: Mediação, 2004.

LODI, A.C.B.; HARRISON, K. M.P.; CAMPOS, S.R.L. "Letramento e surdez: um olhar sobre as particularidades dentro do contexto educacional". In: LODI, A.C.B.; HARRISON, K.M.P.; CAMPOS, S.R.L.; TESKE, O. (Orgs.) Letramento e minorias. Porto Alegre: Mediação, p.35-46, 2002.

LODI, A.C.B.; HARRISON, K.M.P.; CAMPOS, S.R.L.; TESKE, O. (Orgs.) Letramento e minorias. Porto Alegre: Mediação, 2002.

LODI, A.C.B.; MÉLO, A.D.B.; FERNANDES, E. (Orgs.) Letramento, bilinguismo e educação de surdos. Porto Alegre: Mediação, 2012.

LODI, A.C.B. "O poder da escrita e a escrita do poder". In: LODI, A.C.B.; HARRISON, K.M.P.; CAMPOS, S.R.L. (Orgs.) Leitura e escrita: no contexto da diversidade. Porto Alegre: Mediação, p.19-26, 2004.

MONTEIRO, M.S. História dos movimentos dos surdos e o reconhecimento da Libras no Brasil. ETD - Educação Temática Digital, [S.L] v. 7, n.2, p. 295-305, 2006.

NOGUEIRA, A.S. Interface do português com a língua de sinais em publicações de um professor surdo em rede social. Linguagem em (Dis)curso - LemD, Tubarão, SC, v.18.n.3, p.673-694, 2018. Disponível em: http://www.scielo.br/pdf/ld/v18n3/1518-7632-ld-18-0300673.pdf Acess: 12 April. 2019

NOGUEIRA, A.S. 'O surdo não ouve, mas tem olho vivo.' - A leitura de imagens por alunos surdos em tempos de práticas multimodais. Tese (Doutorado) - Universidade Estadual de Campinas, Instituto de Estudos da Linguagem. Campinas, SP, 2015. Disponível em: http://repositorio.unicamp.br/jspui/handle/REPOSIP/269526 Acess: 12 April. 2019 
PEREIRA, M.C.C. "Papel da língua de sinais na aquisição da escrita por estudantes surdos". In: LODI, A.C.B.; HARRISON, K.M.P.; CAMPOS, S.R.L.; TESKE, O. (Orgs.) Letramento e minorias. Porto Alegre: Mediação, p. 47-55, 2002.

PEREIRA, M.C.C. O ensino de português como segunda língua para surdos: princípios teóricos e metodológicos. Educ. rev., Curitiba, n. especial 2, p.143-157, 2014. Disponível em: http://www.scielo.br/scielo.php?script=sci arttext\&pid=S010440602014000600011\&lng=en\&nrm=iso Acess: 14 April. 2019.

QUADROS, R.M.; SOUSA, A.N. "Síntese linguística na oralidade e na escrita de bilíngues bimodais". In: SILVA, I.R.; SILVA, M.P.M. (Orgs.) Letramento na diversidade: surdos aprendendo a ler/escrever. Campinas, SP: Mercado de Letras, p.13-40, 2018.

RANGEL, G.; STUMPF, M.R. “A pedagogia da diferença para o surdo”. In: LODI, A.C.B.; HARRISON, K.M.P.; CAMPOS, S.R.L. (Orgs.) Leitura e escrita: no contexto da diversidade. Porto Alegre: Mediação, p. 86-97, 2004.

RODRIGUES, C.H. "Reflexões sobre o processo de ensino aprendizagem em turmas com surdos e de surdos". In: SILVA, I.R.; SILVA, M.P.M. (Orgs.) Letramento na diversidade: surdos aprendendo a ler/escrever. Campinas, SP: Mercado de Letras, p.75-106, 2018.

ROJO, R. Alfabetização e letramento: perspectivas linguísticas. Campinas: Mercado das Letras, 1998.

ROJO, R. Letramentos múltiplos, escola e inclusão social. São Paulo: Parábola Editorial, 2009.

SANDER, R. "Questões do intérprete da língua de sinais na universidade". In: LODI, A.C.B.; HARRISON, K.M.P.; CAMPOS, S.R.L.; TESKE, O. (Orgs.) Letramento e minorias. Porto Alegre: Mediação, p.129-135, 2002.

SCHULTZ, K.; HULL, G. "Literacies in and out of school in the United States". In: STREET, B.V.; MAY, S. (Eds.) Literacies and Language Education. Springer International Publishings, 2017.

SIGNORINI, I. (Org.) Investigando a relação oral/escrito e as teorias do letramento. Campinas, SP: Mercado das Letras, 2001.

SIGNORINI, I. "Literacy". In: STRAZNY, P. (Ed.) Encyclopedia of Linguistics. New York: Routledge UK, p. 627-629, 2004. Disponível em: https://www.academia.edu/34582736/ Literacy. Acess: 12 abr. 2019

SILVA, G.M. "Interações em sala de aula e o processo de ensino-aprendizagem da leitura em português no caso de aprendizes surdos". In: SILVA, I.R.; SILVA, M.P.M. (Orgs.) Letramento na diversidade: surdos aprendendo a ler/escrever. Campinas, SP: Mercado de Letras, p.41-74, 2018.

SILVA, I.R. KUMADA, K.M.O;; AMADO, B.C. "Libras, português e ciências para surdos: reflexões necessárias para uma prática escolar bilíngue". In: SILVA, I.R.; SILVA, M.P.M. 
(Orgs.) Letramento na diversidade: surdos aprendendo a ler/escrever. Campinas, SP: Mercado de Letras, p. 267-292, 2018.

SILVA, I.R.; SILVA, M.P.M. (Orgs.) Letramento na diversidade: surdos aprendendo a ler/escrever. Campinas, SP: Mercado de Letras, 2018.

SKLIAR, C. A surdez: um olhar sobre as diferenças. Porto Alegre: Mediação, 1998.

SKLIAR, C. Prefácio. "A pergunta pelo outro da língua; a pergunta pelo mesmo da língua". In: LODI, A.C.B.; HARRISON, K.M.P.; CAMPOS, S.R.L.; TESKE, O. (Orgs.) Letramento e minorias. Porto Alegre: Mediação, p. 5-12, 2002.

SKLIAR, C. Uma análise preliminar das variáveis que intervêm no projeto de educação bilíngue para surdos. Espaço (INES-MEC), v. 4, n. 6, p. 49-57, 1997.

SOUZA, R.M. "Educação de surdos e questões de norma". In: LODI, A.C.B.; HARRISON, K.M.P.; CAMPOS, S.R.L.; TESKE, O. (Orgs.) Letramento e minorias. Porto Alegre: Mediação, p.136-143, 2002.

STREET, B.V. Literacy in Theory and Practice. Cambridge: Cambridge University Press, 1984.

STREET, B.V. "New literacies, new times: developments in literacy studies". In: STREET, B.V.; MAY, S. (Eds.) Literacies and Language Education. Springer International Publishings, 2017.

STUMPF, M.R. "Transcrições de língua de sinais brasileira em signwriting". In: LODI, A.C.B.; HARRISON, K.M.P.; CAMPOS, S.R.L.; TESKE, O. (Orgs.) Letramento e minorias. Porto Alegre: Mediação, p.62-70, 2002.

TERZI, S.B. A construção da leitura: uma experiência com crianças de meios iletrados. Campinas, SP: Pontes, 2001.

TESKE, O. "Surdos: um debate sobre letramento e minorias". In: LODI, A.C.B.; MÉLO, A.D.B.; FERNANDES, E. (Orgs.) Letramento, bilinguismo e educação de surdos. Porto Alegre: Mediação, 2012.

Aryane S. Nogueira aryane.santos.nogueira@gmail.com

Recebido em: 11 de Julho de 2019 Aceito em: 22 de Agosto de 2019

Publicado em: Setembro de 2019 